\title{
Energy Poverty Policies at the EU Level
}

\begin{abstract}
This chapter explores the historical evolution and present content of a common European Union (EU) energy poverty agenda. It identifies the principal institutional and political drivers of this process, as well as the ways in which it has been translated into formal legal and policy documents. Also discussed are the key actors involved in promoting energy poverty-relevant policies, as well as recent trends in the development of a more coherent programme to address the difficulties faced by vulnerable groups. The chapter argues that EU energy poverty policy has been limited by the subsidiarity principle, and as such has been largely shaped by instruments related to the Single Market, even if energy efficiency and social policy-related efforts have also played a role.
\end{abstract}

Keywords Energy poverty $\bullet$ European Single Market $\bullet$ Policy subsidiarity - Energy transitions $\bullet$ European Union

\section{INTRODUCTION}

This chapter provides an overview of how EU policy on energy poverty has emerged and developed over time. It details the content and structure of relevant policy tools and legislation in the context of Europe's energy poverty-related infrastructural divide. In Bouzarovski and Petrova (2015b), we argued that in decision-maker and academic 
circles alike, the concept of 'EU energy policy' is generally associated with measures to address residential and industrial consumption practices or transnational security issues. There has been little recognition or knowledge of the fact that the EU is becoming increasingly involved in a new strategic effort situated at the intersection of household fuel use, affordability and residential energy efficiency. Given the significant overlap between notions of energy poverty and energy vulnerability, the chapter uses both terms in its review of relevant policy and literature, conceiving them as policies, events or characteristics that jeopardize the affordability or accessibility of energy at any level of the energy system. In mapping 'EU-led policies' the chapter examines explicit EU official documents and legislation on energy vulnerability and energy poverty, as well as related published papers that reference these concepts or have implications for the EU's approach. National policies are referenced only insofar as they have taken EU policy as a basis or have been altered to reflect EU initiatives.

On the basis of these parameters, the chapter first gives a structural account of the major policy initiatives introduced since 1957, including their formal and informal content, any change over time, the driving actors and stakeholders, the relation to energy policy realities 'on the ground' and, where applicable, their perceived success. To do so, it examines primary and secondary EU law, as well as related research and public statements, and supplements these sources with a review of the academic literature. Data is drawn from systematic searches of the EU law and publications database (EUR-Lex), the EU Community Research and Development Information Service (CORDIS), the website archives of the European Commission's Directorate General (DG) for Energy, the catalogue of the British Library, back issues of three high-ranking academic journals in the field (Energy Policy, the International Journal of Justice and Sustainability and Environment and Planning) and the Google Scholar search engine. Each of the search results is then methodically reviewed and any relevant sources within it added to the collection of resources.

Traditionally, there has been limited discussion of the systemic processes that lie behind the political acceptance of energy poverty at the European scale, especially in terms of the power actors, interests and relations that have driven the increasing prominence of this issue within EU regulation and debates (Bouzarovski \& Petrova, 2015a). The academic literature that deals with EU policy on energy poverty contains little 
research or commentary on EU-level approaches to combat energy poverty or the impact of EU energy policy frameworks upon social inequality. The few exceptions are Darby's (2012) study on the impact of EU metering policy upon fuel-poor households, Bouzarovski, Petrova and Sarlamanov's (2012) critique of EU energy poverty policies, Bouzarovski and Petrova's (2015b) exploration of EU energy poverty work in the context of EU agenda-setting, Hiteva's (2013) examination of renewables policy and its implications for energy vulnerability as well as Thomson, Snell and Liddell's (2016) discussion of definitional issues surrounding energy poverty in the EU. Also of relevance is Dubois and Meier's (2016) work on how energy poverty patterns in Europe are of relevance for policymaking processes.

International-level institutions and organizations active in energy policy have offered a number of assessments and analyses of the energy vulnerability challenge, taking a global perspective and tending to focus upon access to energy in developing countries and the global dimension of security of supply. Such policy recommendations are not generally specific to any given country or system, and do not comment on the construction of EU policy in this area. Similarly, national-level organizations have tended to analyse national-level policy and prevalence, making reference to the EU only where specific laws and regulations are derived from Brussels, such as the Energy Efficiency Directive (EED). For a long time, EU-led policy research in the energy poverty domain was relatively absent-as reflected in the lack of attention devoted to the problem in work by the European Parliamentary Research Service, its internal think tank and the Commission's Joint Research Centre. As is argued in the text that follows, however, this situation has started to change in recent years.

The chapter is chronologically structured, mapping the evolution of energy poverty policy over time, but drawing out key thematic issues and exploring these in more depth when relevant to the key aims of the book. After walking through the foundations of the modern policy framework, the organization of the argument reflects the three main 'sources' of current energy poverty policy, identified as the Third Energy Package (TEP), the EED and various social policy provisions (European Commission, 2013c). A final section provides an analysis of the governance structure that now characterizes energy poverty policy, before short conclusions are offered. Firstly, however, I examine the broader context of EU energy policy and law, which frames energy poverty policy. 


\section{The Context: EU Energy Policy}

As we pointed out in Bouzarovski and Petrova (2015b), the lack of attention towards EU energy poverty policy has transpired despite the fact that the constituent dynamics of some of the political developments and institutional structures associated with adjacent programmatic sectors are well known. There is, thus, a sizeable body of research on the underlying principles and implementation challenges associated with EU policy in the environmental policy and security domains (McCormick, 2014).

A common EU energy policy did not exist in any coherent form until 2007. After initial integration under the founding treaties, the EU energy policy became marginalized and irrelevant as the dominant energy mix shifted from coal- to oil-based in the early 1960s (Duffield \& Birchfield, 2011). While the EU had a solid legal mandate concerning coal, it did not enjoy similar powers in relation to oil. Since Member States were not willing to update the relevant institutional mandates, the EU's role became limited-every decade from the 1950s to the 1990s saw attempts to create a common energy policy but to little avail (Duffield \& Birchfield, 2011). Proposals on an energy chapter in the Maastricht Treaty were dropped and a 1995 White Paper was met with indifference and opposition from Member States (Commission of the European Communities, 2005).

The First Energy Package (consisting of directives 96/92/EC and 98/30/EC) was launched in 1997 and sought to harness the momentum of the Single Market and signalled the beginning of a renewed effort in the creation of a common energy policy, as well as a series of developments in energy-environmental and energy-external relations policy. Statements of coherent policy objectives began to be published in the mid-2000s, reaching a peak with the Second Energy Package (consisting of Directive 2003/54/EC, Directive 2003/55/EC, Regulation 1228/2003 and Regulation 1775/2005) in July 2007, and were supported by comparable efforts in the Council and the European Parliament (Duffield \& Birchfield, 2011). The Energy Policy Communication was followed by commitment to an action plan by Member States and also formed the basis for the 2008 Energy and Climate Package. Finally, this proliferation of energy instruments and the imminent publication of the TEP (consisting of Directive 2009/72/EC, Directive 2009/73/EC, Regulation 713/2009, Regulation 714/2009 and Regulation 715/2009) were captured by the inclusion of a dedicated title in the Lisbon Treaty in 2009.

Energy was at the centre of the founding treaties - the European Coal and Steel Community (ECSC) and Atomic Energy (Euratom) treaties 
formed a common policy based on supranational powers and a central authority. However, subsequent accords of this kind did not develop an overarching legal basis for the EU energy policy and when the ECSC Treaty expired in 2002, the Euratom Treaty, relating only to the nuclear energy sector, was the only remaining legal basis (Andoura, Hancher, \& van der Woude, 2010). Seeking to address this absence of mandate, the Lisbon Treaty contains for the first time a dedicated Title on energy which sets out the four main aims of the EU's policy. However, it does little to change the parameters of energy policy development, instead constituting 'a carefully crafted compromise between national sovereignty over natural resources and energy taxation on the one hand, and shared EU competence for other areas on the other' (Andoura et al., 2010, p. 19).

The current provisions, embodied in Title XXI (Article 194) of the Treaty on the Functioning of the EU (TFEU), state that (Official Journal of the European Union, 2012):

1. In the context of the establishment and functioning of the internal market and with regard for the need to preserve and improve the environment, Union policy on energy shall aim, in a spirit of solidarity between Member States, to:

a) ensure the functioning of the energy market;

b) ensure security of energy supply in the Union;

c) promote energy efficiency and energy saving and the development of new and renewable forms of energy; and

d) promote the interconnection of energy networks

2. Without prejudice to the application of other provisions in the Treaties, the European Parliament and the Council, acting in accordance with the ordinary legislative procedure, shall establish the measures necessary to achieve the objectives in paragraph 1 . Such measures shall be adopted after consultation of the Economic and Social Committee and the Committee or the Regions.

Such measures shall not affect a Member State's right to determine the conditions for exploiting its energy resources, its choice between different energy sources and the general structure of its energy supply.

Additionally, Declaration 35, annexed to the TFEU by the intergovernmental conference that adopted the Lisbon Treaty, states that: 
The Conference believes that Article 194 does not affect the right of the Member States to take the necessary measures to ensure their energy supply under the conditions provided for in Article 347.

Article 347 of the TFEU commits Member States to consult with each other so as to protect the functioning of the internal market in the event that a member state has to take action relating to internal disturbances, international tension or the threat of war or the maintenance of law and order. Finally, Article 122 expands upon the notion of solidarity in this context, stating that:

Without prejudice to any other procedures provided for in the Treaties, the Council, on a proposal from the Commission, may decide, in a spirit of solidarity between Member States, upon the measures appropriate to the economic situation, in particular if severe difficulties arise in the supply of certain products, notably in the area of energy.

As pointed out by Duffield and Birchfield (2011, p. 4), 'the crucial implication of Title XXI is that it removes any equivocation about the legal basis of EU activity in the energy field'. The fact that energy is still a shared competence allows EU energy initiatives to move beyond a 'piecemeal' approach 'based on tenuous links to existing mandates in market liberalization and environmental policy' (ibid.). This overall set of circumstances allowed the European Commission to publish its Communication on the Energy Union in February 2015 (European Commission, 2015). The document calls for a fundamental transformation of Europe's energy system, leading to a global voice on energy on the behalf of the EU, as well as the building of a sustainable and low-carbon economy within the EU. The liberalization of cross-border energy trade is another key tenet of the Communication, as well as the optimization of resource use and the empowerment of citizens in driving energy transitions forward. The reduction of energy bills via new technologies, active market participation, energy efficiency investment and the protection of vulnerable consumers also feature prominently within this document.

Two other overarching frameworks that have guided EU energy policy are the Europe 20-20-20 Strategy (and the Climate and Energy Package adopted within it) and the Energy Roadmap 2050. The 20-20-20 Strategy seeks a 20 per cent reduction in EU greenhouse gas emissions from 1990 levels, an increase in the proportion of EU energy produced from 
renewable resources to 20 per cent and a 20 per cent improvement in the EU's energy efficiency. The Energy Roadmap also aims to reduce EU emissions by 80 per cent by 2050 via a programme of decarbonization. In a communication produced by the European Commission in 2011, it was stated that 'vulnerable consumers are best protected from energy poverty through a full implementation by Member States of the existing EU energy legislation and use of innovative energy efficiency solutions' while emphasizing that 'the social aspects of energy pricing should be reflected in the energy policy of Member States' since 'energy poverty is one of the sources of poverty in Europe' (European Commission, 2011). Subsequently, the European Parliament:

welcomes the inclusion of the social dimension in the Energy Roadmap 2050; considers that, in this respect, special attention should be given to energy poverty and employment; insists, with regard to energy poverty, that energy should be affordable for all, and calls on the Commission and the Member States, and on local authorities and competent social bodies, to work together on tailored solutions to counter such issues as electricity and heat poverty, with a special emphasis on low-income, vulnerable households that are most affected by higher energy prices. (European Parliament, 2013a)

\section{Energy as a Human Right}

The European Commission's Group on Ethics in Science and New Technologies (EGE) outlined in its 2013 opinion the international human rights framework and the way in which it supports the notion of access to energy as a fundamental human right. While this statement is not made explicitly in the major international treaties, the EGE finds it to be implicit in provisions, such as those in the 1966 Covenants on economic, social and cultural rights, which set out a number of rights essential for the realization of the right to an adequate standard of living, and the Charter of Fundamental Rights of the EU, which states that the Union recognizes and respects access to services of general economic interest (European Group on Ethics in Science and New Technologies to the European Commission, 2013). Though the latter term is not defined, subsequent interpretation by the Commission and the Court has found it to encompass energy provision. The status of the Charter is such that this is not a directly conferred European right, but that the EU may not take legislative 
steps which curtail access to energy, thus presenting a line of defence for advocates of energy access as a human right (European Group on Ethics in Science and New Technologies to the European Commission, 2013). The EGE also recognizes access to energy and the combatting of energy poverty as one of the key ethical challenges facing EU energy policy.

More recently, a group of advocacy groups led by the European AntiPoverty Network and Greenpeace have argued that the eradication of energy poverty in Europe would hinge upon implementing 'a right to energy for all citizens' in all EU legislation. They have taken this to mean prohibiting disconnections, maintaining regulated prices for domestic consumers and allowing low-income households to benefit from specific social tariffs. They have also argued that overcoming energy poverty

will require a holistic political approach, linking social and environmental policy. The economic crisis, ensuing austerity policies and the growing precariousness of the labour market remain the main drivers of the rise of poverty in Europe, however, it is crucial to recognize the role of energy policies in the rise of this issue. ... Awareness is also increasing at national levels, as more and more public bodies, organisations and social movements deepen their understanding of the specificity of energy poverty. But awareness alone will not deliver: it is time for political action to fight energy poverty at the European level. (European Anti-Poverty Network, 2017)

However, the right to energy remains a widely debated issue in the academic literature, since the entity to which the right would be ascribed remains unclear: inter alia, the right to 'energy' itself can consist of legal supplier obligations, end-use services or the possibility of demand (Walker, 2015). Analogous debates of the 'right to water' have also warned against the possibility of introducing a neoliberal lexicon to the debate (Bakker, 2007).

\section{Foundations of EU Energy Poverty Policy, 1957-2007}

Reflecting the broader evolution of energy policy, energy poverty policy as a coherent EU issue did not exist prior to 2007. A EUR-Lex search finds just six documents of secondary EU law mentioning 'energy vulnerability' or 'energy poverty' in the 50 years from 1957; these terms do not feature at all in the primary law of the period. 
Neither the First Energy Package nor the Second Energy Package contained any reference to energy vulnerability or energy poverty. Early recognition of this phenomenon in the EU came in the form of a series of policy documents on sustainable development and EU external assistance. The EU Energy Initiative for Poverty Reduction and Sustainable Development, launched in 2002 at the World Summit on Sustainable Development in Johannesburg, linked access to energy in developing countries to achievement of the Millennium Development. The link between poverty reduction and energy is further developed in EU cooperation with countries in the Global South, and later in the Global Energy Efficiency and Renewable Energy Fund.

It was not until 2006 that energy poverty was introduced as an EU issue by the European Commission. In a Communication on prospects for the internal markets in electricity and gas, the Commission pledged to review national approaches to energy poverty and to launch a 'major information and awareness raising campaign' in the run-up to the full market opening in 2007, including the creation of an Energy Consumers' Charter (ECC). A report on economic and social cohesion identified energy poverty as a social issue and these themes were built into the Commission's Communication on an energy policy for Europe.

In its 2007 Communication, 'An energy policy for Europe', the Commission identified sustainability, security of supply and competitiveness as the three main challenges facing EU energy policy (Commission of the European Communities, 2007). In proposing an ECC, the Commission prioritized an understanding of energy as a public service that forms a central part of the modern energy policy framework. The European Council was quick to offer its support to the Commission's latest attempt to kick-start a common policy, agreeing on an action plan for the next two years (Council of the European Union, 2007). The measures proposed were comprehensive, but did not include reference to energy poverty or vulnerable consumers. Nonetheless, the collective momentum provided by the Commission and the Council fed into the establishment of a dedicated title in the Lisbon Treaty, providing a basis for moves towards a coherent common energy policy.

A helpful contribution towards greater public recognition of energy poverty was made by the European Fuel Poverty and Energy Efficiency project, which received European Commission funding under the Intelligent Energy for Europe programme between 2006 and 2009, and focused upon fuel poverty as an inability to adequately heat the home at 
an affordable cost (Intelligent Energy Europe, 2017). A partnership between agencies in the UK, France, Belgium, Italy and Spain sought to raise the profile of fuel poverty and examine the potential for a common European response. Its final report listed a range of causes and indicators and estimated that fuel poverty affects between 50 and 125 million people in Europe. The project's recommendations identified four core actions that should be undertaken at the EU level-a common definition, a legislative framework, a consistent diagnosis and a fuel poverty special interest group.

As I and Petrova (2015a) have previously pointed out, the European energy poverty sphere has also been influenced by the activities of the Council of Europe (CoE) in the domain of housing policy. This is reflected in a CoE report on the issue (Council of Europe, 2008) drafted by the group of specialists on housing policies for social cohesion. The report aims to aid the improvement of housing access among vulnerable social groups in Europe and has resulted in a set of specific guidelines. These stipulate the key prerequisites for an effective housing policy in the energy while listing a range of potential policy tools. Such efforts have been further assisted by the increasing role of the European Court of Human Rights and case law under the Revised European Social Charter with its associated collective complaints mechanism. As stated in the $\mathrm{CoE}$ report,

It is the Revised European Social Charter which gave a special emphasis to the housing problems of vulnerable social groups, which were reinforced by the CoE's Revised Strategy for Social Cohesion. (Council of Europe, 2008, p. 9)

\section{The Third Energy Package and Vulnerable Consumers, 2009}

The momentum behind the energy chapter in the Lisbon Treaty was also a driving force in the drafting of the TEP, which brings energy poverty and vulnerability into mainstream EU energy policy and establishes it as a European issue. The TEP consists of two directives-2009/72/EC on the internal market for electricity and $2009 / 73$ /EC on the internal market for natural gas-and three regulations concerning cross-border exchanges in electricity, transmission networks for natural gas and establishing the Agency for the Cooperation of Energy Regulators. In both 
directives (Paragraph 53 and Article 3 in Directive 2009/72/EC and paragraph 50 and Article 3 in Directive 2009/73/EC) an identical paragraph in the preamble and article in the main text identifies energy poverty as a 'growing problem' and requires action from Member States in two fields. Firstly, they must adopt a definition of the 'vulnerable consumer' and, secondly, they should ensure adequate protection for vulnerable consumers:

Each Member State shall define the concept of vulnerable customers which may refer to energy poverty and, inter alia, to the prohibition of disconnection of gas to such customers in critical times. (Official Journal of the European Union, 2009, p. 211/103)

In line with the requirement to define vulnerable consumers in the TEP, Member States and national regulators have constructed countryspecific characterizations of vulnerable consumers for use in national systems. The Council of European Energy Regulators (CEER) surveyed national regulators in 2012 and found that in 17 out of 26 countries the concept was included in energy laws or non-energy-sector laws, but cautioned that claiming not to have a formal definition does not mean that a given country does not have any protective measures in place (Council of European Energy Regulators, 2012). The review found that formal definitions range from targeting specific individuals to encompassing whole groups, but those countries without an explicit definition generally have as many protective measures as those with them. A similar review of the retail electricity market commissioned by Directorate General for Health and Consumers (SANCO) found that in Member States with a definition of 'energy poor' or 'non-affordable energy income threshold', the main criteria used are income thresholds, share of income required to meet adequate fuel requirements and consumer characteristics such as age and illness (Directorate General for Health and Consumers, 2010). The share of the population falling within the official definition of energy poor, though only established for three Member States, was found to vary between 6.6 and 18 per cent (ibid.).

While there is still no European consensus on what constitutes energy poverty, a 2010 Commission working paper suggested that those in energy poverty could be defined as 'households that spend more than a predefined threshold share of their overall consumption expenditure on energy products', where the threshold equals 'double of the national 
average ratio number' (European Commission, 2010a, pp. 10-16). A 2016 staff working document also carefully evaluates the EU's regulatory framework for electricity market design and consumer protection in the fields of electricity and gas, discussing existing Member State definitions of energy poverty and vulnerable consumers (European Commission, 2016).

A number of EU documents contain operational definitions which, while not specific to the energy sector, can form a basis upon which national definitions might be constructed. Directive 2005/29/EC on unfair practices in the internal market, for example, established a set of criteria that indicate how consumers might be vulnerable to unfair selling practices with regard to mental or physical infirmity, age and credulity. These general criteria covered a wide range of situations and were built upon in the European Parliament Resolution on strengthening the rights of vulnerable consumers, which examined extending the concept to 'include consumers in a situation of vulnerability, meaning consumers who are placed in a state of temporary powerlessness resulting from a gap between their individual state and characteristics on the one hand, and their external environment on the other hand' (European Parliament, 2012, p. 6). Directive 2009/73/EC itself states:

Member States shall take appropriate measures to protect final customers, and shall, in particular, ensure that there are adequate safeguards to protect vulnerable customers. (Official Journal of the European Union, 2009, p. $211 / 103)$

In its report on progress in the completion of the Internal Energy Market (IEM) in 2013, the European Council noted how many Member States have taken measures to protect vulnerable consumers and listed a number of examples: 'establishing a definition of vulnerable consumers for policy purposes, establishing suppliers of last resort, focused assistance, establishing social tariffs or social discounts, subsidized energy efficiency measures, setting minimum periods before energy deliveries can be suspended in cases of non-payment, prohibitions to cut off energy services during the winter, et cetera' (Council of the European Union, 2013, p. 9). A number of subsequent EU documents on the introduction of the TEP offered broad guidance on national measures that might be introduced, commonly emphasizing the need to use a policy mix that least distorts the IEM and is well targeted to reach only those truly in need of assistance. 
The aforementioned SANCO Report found that most Member States used a combination of economic measures (to ensure prices are affordable and to assist consumers in arrears) and non-economic measures (regulation of the process for arrears and disconnection and support in finding the best tariff and increasing energy efficiency). The main types of measure are special prices offered to certain groups, helping to find the best tariff, energy-related payments (e.g. fuel allowance), grants to improve home energy efficiency and social security benefits (Directorate General for Health and Consumers, 2010). Similarly, the CEER found that Member States commonly employed specific protection measures for customers in remote areas, suppliers of last resort, default suppliers and social tariffs for vulnerable customers (Council of European Energy Regulators, 2012).

Despite having set a target to complete the IEM by 2014, however, the EU struggled to fully implement the provisions of the TEP. The Commission frequently pursued infringement proceedings against Member States not transposing or correctly transposing the TEP and its related legislation. Initially the Commission opened 38 infringement proceedings against 19 Member States, prompting an acceleration of national measures and the closure of many of the proceedings soon after. Additionally, the energy market was consistently identified as a problem in terms of lack of transparency and ease of consumer choice, even if offering considerable benefits in terms of competitiveness and growth. The policy focus on the IEM reflects the strength of the EU's mandate in internal market and consumer protection issues-while the Lisbon Treaty provides a comprehensive legal basis for EU energy policy action, the majority of initiatives and legislation have remained focused upon consumer rights and market liberalization, reflecting the early trajectory of the policy area.

The reliance upon IEM and consumer protection competence has produced an ongoing theme of energy as a public service, which runs throughout EU energy policy and is a key part of energy vulnerability policy. The TEP contains provisions on public service requirements - these capture the idea that energy is a vital public service and should strive for the highest standards of provision. Although these requirements are meant to be established at the national level, the EU advises that they should ensure fair pricing and competition, access to objective and transparent data, security of supply and mechanisms for the protection of vulnerable consumers. 
The public service requirements build upon the idea of public service obligations (PSOs) included in early EU energy policy and highlighted in the Commission's 2007 Communication on an energy policy for Europe. In it, the Commission notes that PSOs do not go far enough and advocates instead for the launch of an ECC which should have as goal one to 'assist in establishing schemes to help the most vulnerable citizens deal with increases in energy prices' (Commission of the European Communities, 2007, p. 10). The ECC was eventually dropped-with its main provisions included in the TEP-but remained emblematic of the centrality of consumer protection in EU energy poverty and vulnerability policy.

\section{Energy Efficiency and Energy Poverty, 2012}

The second major source of energy poverty policy has been the EU's legislative framework on energy efficiency. This has evolved and developed alongside the general flux of energy policy but was most comprehensively captured in the 2012/27/EU EED. This document states in its preamble that national energy efficiency frameworks should ensure that vulnerable consumers have access to the benefits of high energy efficiency and notes the role of energy efficiency in reducing fuel poverty. Furthermore, Article 7 posits that within their energy efficiency targets Member States may include requirements with a social aim in the saving obligations they impose, including by requiring a share of energy efficiency measures to be implemented as a priority in households affected by energy poverty or in social housing' (European Commission, 2017c).

Historical energy efficiency policy in the EU has made little mention of energy vulnerability or fuel poverty, be it in relation to the energy performance of buildings, energy-using products or renewables; Directives 2002/91/EC, 2005/32/EC and 2006/32/EC establishing performance standards all lack provisions on energy vulnerability and poverty. In 2009, the directive on eco-design for energy-using products (Directive $2009 / 125 / E C$ ) was recast but still failed to mention energy vulnerability and poverty. This was only done in the third revision a year later, which notes the role of energy-efficient products in combatting energy poverty (see Directive 2010/31/EU). Finally, Commission guidance on the construction of national energy efficiency action plans has generally made little reference to energy poverty, even if recommending that action plans 
take into consideration the specificities of vulnerable consumers (European Commission, 2013b).

The International Energy Agency (IEA) identifies the difficulty of using energy efficiency regulation to tackle fuel poverty as the poor return on investment-often government spending-shown at evaluation. Most of the benefits are provided in the long term and are made not only to energy bills, but to tenants, property owners, energy providers, local communities and society as a whole, meaning that traditional cost-benefit analysis tends to misrepresent the return on initial capital. To address this and related issues, the IEA established a programme on innovative energy efficiency policies for mitigating fuel poverty, which seeks to take account of the wider benefits of energy efficiency as a tool for reducing fuel poverty (Heffner \& Campbell, 2011).

Though there is considerable potential for the development of energy poverty policy through the EU's energy efficiency framework, this has been limited as policy has tended to prioritize climate change, commercial and environmental objectives over energy poverty goals. In the long term, many of the aims of climate change and energy poverty policy are entirely compatible and mutually reinforcing. But in the short term, policy tools for addressing energy poverty have tended to involve financial aid as part of national social policy and energy pricing policy, serving to relieve the financial burden rather than reducing energy consumption via more efficient buildings and products. Meanwhile, short-term climate change policies tend to increase costs for the end user by imposing higher regulatory standards and prices. A Commission Green Paper noted the impact on energy prices, adversely impacting affordability of energy for vulnerable households and the competitiveness of energy intensive sectors even though they may reduce industry's exposure to energy costs and improve resilience to energy price peaks', while the 2020 climate change goals make no reference to energy poverty (European Commission, 2013a, p. 10).

\section{Social Policy, Economic Crisis and the Vulnerability 'Policy Mix'}

The third main source of EU energy vulnerability policy has been social policy; though in itself this is a misnomer, since social policy is a largely national competence. Social policy measures to combat energy poverty typically take the form of financial assistance-social tariffs, lower tariffs of 
subsidies made available to vulnerable consumers, such as winter and cold weather payments for the elderly or disabled (European Commission, 2013c). A small but consistent thread of reference to the social dimension of energy policy exists throughout its evolution and, in the wake of the economic crisis and concerns about rising costs and vulnerable populations, this has taken on a new significance.

At the launch of the Europe 2020 Strategy in 2010, the European Commission noted that 'to lift people out of poverty will require access to energy since achieving the goal of eradicating extreme poverty by 2015 cannot be met unless substantial progress is made on improving access' (European Commission, 2010b, p. 17). This was the first statement linking energy to poverty eradication within the EU context, as opposed to external relations and development. It was soon followed by number of similar policy statements. During the discussion of the 2050 Energy Roadmap, the Commission stated that 'as energy poverty is one of the sources of poverty in Europe, the social aspects of energy pricing should be reflected in the energy policy of Member States' (European Commission, 2011, p. 17), while the Parliament welcomed the inclusion of a social dimension and insisted that the issue of energy poverty be given special attention.

An important social policy statement on energy poverty was made by the European Economic and Social Committee (EESC), which highlighted the importance of links with other sectors, such as health, consumer rights and housing, urging Member States to do more to combat energy poverty and calling on the Commission to establish a European Energy Poverty Monitoring Centre to provide better research and facilitate the mainstreaming of energy poverty into other policy areas (European Economic and Social Committee, 2011). The EESC asserted:

The European Union legislates on energy policy, has powers in this field and consequently has an impact, whether direct or indirect, on energy poverty in the Member States. The EU must, therefore, act and deliver policies within its sphere of competence. (European Economic and Social Committee, 2011, p. 44/56)

Drawing on the EESC's calls for an intersectoral approach to energy poverty, the European Parliament included a dedicated section on combatting energy poverty in its 2012 Resolution on social housing (European Parliament, 2013b). This called for energy-efficiency standards to be incorporated into definitions of 'decent housing' and stated that access to 
energy should be considered a requirement in order for people to lead a 'dignified life'. The Parliament called on Member States to enact a series of measures to combat energy poverty including financial schemes and regional funds to assist vulnerable consumers, programmes of incentives and instructive measures to help residents reduce energy consumption and long-term financial leverage instruments to make buildings more energy efficient. In drawing a link to public health, the Resolution noted that measures to reduce energy poverty can help to tackle illnesses including 'respiratory and cardiovascular conditions, allergies, asthma, food and carbon monoxide poisoning, and impacts on mental health'. Emphasizing the need to utilize energy, consumer and social policy to tackle energy poverty, the Council called on the Commission to provide a follow-up review on these issues by 2016 (Council of the European Union, 2014b).

The post-2008 financial crisis and economic recession prompted Member States and the EU institutions to look closer at national expenditure. A 2014 report on energy prices and costs in Europe drew a link between the economic crisis, rising prices and energy poverty, noting that 'the on-going financial and economic crisis makes addressing energy poverty and/or vulnerability more important today, given that energy cost rises are hitting poor households harder' (European Commission, 2014b, p. 14). European Council conclusions have confirmed a similar focus, discussing high energy costs and affordable energy prices as priorities in the completion of the IEM, also calling for 'sustained efforts to moderate the energy costs borne by energy end-users' (European Commission, 2014c, p. 1). Also, the Council of the EU, in its discussions on the rising cost of energy in Europe, has urged Member States to use cost-effectiveness and price contestability to protect both vulnerable consumers and competitiveness.

\section{Revolutionizing EU Energy Poverty Policy: The Clean Energy Package}

In recent years, the European Commission has taken a further lead in advancing the EU energy poverty agenda. This has been primarily achieved via the co-ordination of a project aimed at investigating the policies and measures currently in place to protect 'vulnerable consumers' in the energy sector across the EU (Pye et al., 2015). In addition to discussing the multiple meanings and understandings of vulnerability, this document emphasizes that 
many measures are being implemented across Member States, focused both on vulnerable consumers and on energy poverty. However, these are distinct issues, and are targeted by different types of measures. Measures focused on vulnerable consumers offer protection within regulated markets, and facilitate access and participation. They are often short-term in nature, providing relief or ensuring on-going supply in the face of indebtedness. Energy poverty measures on the other hand are explicitly focused on lower income households, and seek to address longer term structural problems of building energy efficiency. (Pye et al., 2015, p. vii)

A further Commission-sponsored report (Rademaekers et al., 2016) has dealt with the identification of ways to measure the problem, proposing four key indicators tested and computed for the Netherlands, Slovakia, Spain and Italy using currently available data. The Commission has also supported the publication of an extensive analysis of the components of energy prices and costs in Europe, with an emphasis on household energy budgets among different income groups (Grave et al., 2016). This document points to the inflationary character of taxes, levies and network charges on final energy prices in Europe, while underlining that the main impact of increasing retail prices is on low-income households:

In some countries, increasing average energy costs have been compensated by increasing average income, thus, mitigating price effects. However, low income households have high shares of residential energy expenditures and are affected most by changes in energy retail prices. A number of countries introduced policies to support households with low income to keep their standards of living, either through issuing allowances to cover costs for heating, or by reduced tariffs per unit of energy. (Grave et al., 2016, p. 6)

As a whole, this body of work has helped establish the state of the art in terms of policy knowledge and the measurement of energy poverty, while further affirming the importance of energy poverty as a decision-making concern across the European context. The three reports have identified the diversity of measures, drivers and circumstances that can be attributed to energy poverty, bringing out the difficulties associated with capturing the problem via a single indicator. They have pointed to a lack of consistency in the understanding and treatment of energy poverty at the level of Member States-with some countries treating the issue as a social policy challenge, and others developing a more comprehensive approach: 
It would also be possible to further improve the data available from existing surveys. As mentioned in the report, while there have been efforts for harmonization, differences remain in frequency, timing, content and structure of the Household Budget Surveys. A number of recommendations are available to improve datasets at the EU level to further enhance the measurement of energy poverty. One specific simple recommendation is to include a variable in the SILC survey that refers to the total energy spending. If this were the case, it would be possible to calculate all energy poverty metrics from this survey. (Rademaekers et al., 2016, p. 98)

The 'Clean Energy for all Europeans' package has allowed for the materialization of these analytical documents into policy stipulations and legal regulation. The Package is made up of eight legislative proposals targeting a variety of sectors, inlcuding energy efficiency, renewable energy, electricity market redesign, governance rules for the Energy Union, energy security and eco-design. The proposals are currently being discussed within the European Council and European Parliament with a view to being adopted in 2018. Their departure point is a strong declarative commitment to energy efficiency, 'fair treatment' of consumers and global leadership in energy transitions.

A number of the Clean Energy Package proposals explicitly mention energy poverty. For example, the draft of the newly 'recast' Electricity Directive (European Commission, 2017b) maintains the Article 28 Directive 2009/72/EC provision on common rules for the internal market in electricity, which requires Member States to 'define the concept of vulnerable customers which may refer to energy poverty and, inter alia, to the prohibition of disconnection of electricity to such customers in critical times'. In Article 5 of the recast Directive, the European Commission also obliges Member States to ensure protection of energy poor or vulnerable customers 'in a targeted manner by other means than public interventions in the price-setting for the supply of electricity'. The same draft Directive also provides a definition of energy poverty:

Energy poor households are unable to afford these energy services due to a combination of low income, high energy expenditure and poor energy efficiency of their homes. (recital 40)

The new Electricity Directive proposes that Member States should define a set of criteria to measure energy poverty, while being obliged to 
monitor the number of households in energy poverty so as to provide targeted support. In Article 29, it is suggested that Member States 'shall report on the evolution of energy poverty and measures taken to prevent it to the Commission every two years as part of their Integrated National Energy and Climate Progress Reports'.

Also of importance are amendments to the 2012 EED. One of these builds on a key provision stating that Member States 'may include requirements with a social aim in the saving obligations they impose $\ldots$ by requiring a share of energy efficiency measures to be implemented as a priority in households affected by energy poverty or in social housing' (European Commission, 2012, p. 315/16). In the amendments, the provision is modified by replacing 'may' with 'shall'. The new EED also introduces a new requirement whereby 'in designing alternative policy measures to achieve energy savings, Member States shall take into account the effect on households affected by energy poverty' (European Commission, 2017c, p. 20). Also, the draft Energy Performance of Buildings Directive states:

This proposal could contribute to taking out from energy poverty between 515000 and 3.2 million households in the EU (from a total of 23.3 million households living in energy poverty-Eurostat). (European Commission, 2017a, p. 3)

The preamble to the same draft Directive states that the social impacts of energy building improvements will also be felt in the energy poverty domain, while stipulating that the European Commission will require Member States to contribute to the alleviation of energy poverty through their long-term renovation strategy (Article 2).

Last but not the least, Article 21 in the Governance of the Energy Union Regulation affirms that the Member State-level Integrated National Energy and Climate Progress Reports will include information on the implementation of 'national objectives with regards to energy poverty, including the number of households in energy poverty' (European Commission, $2017 \mathrm{~d}$, p. 38 ). The provision of alternative measures for energy savings - such as those relevant to social housing-integrated within the EED are also mentioned.

While it remains unclear, at the time of writing this book, to what extent these extensive provisions will be translated and implemented into binding legal documents, there is little doubt that energy poverty now 
plays a much more pivotal role as a pan-EU concern. Aside from the pioneering role of the European Commission in moving this agenda forward, recent activities in other institutions, notably the European Parliament, have also played a role. This involves the increased frequency and extent of parliamentary debates as well as engagement of specific parliamentary committees: on Industry, Research and Energy; Employment and Social Affairs; and Women's Rights and Gender Equality. Widely cited across policy and scientific circles has been a dedicated European energy poverty handbook (Csiba, 2016) and video (https://youtu.be/0tZ9$9 \mathrm{hmSOw}$ ) published by the Greens/European Free Alliance group; while the Socialists and Democrats adopted a manifesto to 'fight energy poverty' in the context of the Energy Union (S\&D Manifesto, 2017).

Beyond formal political institutions, there is also an ever-expanding polity of European-level think tanks and industrial lobby groups who have published position papers or analytical work on energy poverty. Notable examples include a policy brief issued by the Union of the Electricity Industry highlighting, inter alia, that 'any new policy initiative at EU level should be subject to a distributional impact assessment to make sure that energy customers-especially the most vulnerable ones-will not bear disproportionate risks and unintended consequences' (Eurelectric, 2017, p. 6). The eminent Jacques Delors Institute has also commented on energy poverty (Pellerin-Carlin, Vinois, Rubio, \& Fernandes, 2017) arguing that Europe needs 'a social pact for the energy transition' as well as a 'European action plan to eradicate energy poverty'. The Social Platform has also expressed an interest in the issue (Bouzarovski, 2014), as has the European Policy Centre (Dhéret \& Giuli, 2017).

\section{Energy Poverty Governance: A Hybrid Model}

The evolution of EU energy poverty policy has been directed, for a significant part, by the evolution of the EU's governance system and legal mandates. As a result, one can observe the development of a hybrid model of governance in energy poverty policy, supplementing hard law in strongmandate areas with soft law in those areas where Member States retain autonomy.

The central threads of the EU energy poverty policy have been the IEM and the protection of vulnerable consumers. This is not coincidental, but rather reflects the competence assigned to the EU as a supranational body. Though energy poverty is understood as a social problem and the role of 
social policy in addressing its causes is widely acknowledged, the Commission continues to legislate and project within the bounds of its constitutional asymmetry, elevating the consumer and the proper functioning of the IEM as the focus of policy. Though the changing economic environment has elevated the need to protect vulnerable members of society, social, health and welfare policy remain largely national responsibilities, leaving the EU to tackle issues such as energy poverty from one side-legislating on the internal market and consumer protection while leaving social policy remedies to the Member States.

To get around this imbalance, the EU supplements this well-established internal market and consumer legislation with a vast body of soft law. In 2007, the Commission established the Citizens' Energy Forum (CEF), a platform designed to implement and enforce consumer rights in the energy market, bringing together national consumer organizations, industry, national regulators and government authorities. Initially working on issues such as smart metres, user-friendly billing and switching suppliers, the CEF established a new working group in 2011 , commencing activities in early 2012, to examine the policy framework for the protection of vulnerable consumers. This Vulnerable Consumers Working Group (VCWG), established by DG Energy in close collaboration with SANCO, has had a number of aims and objectives, including to review factors that impact consumers' energy poverty, to assess the drivers of vulnerability, to develop key characteristics of vulnerable consumers and what differentiates them, to consider energy policy and non-energy instruments that can address vulnerability.

The VCWG's activities have included collecting and assessing illustrative existing practices, reviewing data and generating recommendations for action. For the most part, Member States have supported this emphasis upon voluntary collaboration. The Council has endorsed the use of benchmarking and exchange of best practice as appropriate mechanisms for coordination, commonly calling on the Commission to presents 'reviews' or 'reports' rather than legislative solutions. Crucially, Member States agreed in 2015 to the systematic monitoring of key indicators for an 'affordable, safe, competitive, secure and sustainable energy system' (European Council, 2015). This presents a potential foundation for ongoing monitoring of the core factors affecting energy poverty from within the energy sector, to complement current data sources related to income, social housing provision and 'at risk of poverty or social exclusion' status. 
The 2014 European Commission's Communication on energy prices and costs advises Member States that 'for households, fiscal transfers can be considered to provide protection, bearing in mind that it is generally more efficient to protect such vulnerable consumers through social policy measures (such as fiscal transfers) rather than through energy pricing' (European Commission, 2014b, p. 243). Similar conclusions about the optimal policy mix and the risks of using energy pricing as a lever are made by the Council and in the TEP. Yet the staff working document that accompanies the Commission's 2014 Communication stated that 'social tariffs may distort the market, do not encourage energy-efficient behaviour, and have a proportionally higher financial impact on those who fall just outside the vulnerable classification' (European Commission, 2014a, p. 243).

This shift in the recommended policy mix is also reflected in policy statements which encourage the use of 'coordinated and balanced social, energy and consumer policy, as determined by each Member State to combat energy poverty' (Council of the European Union, 2014a, p. 5). Earlier references mentioned primarily energy and social policy, while noting clearly that the latter remained a matter of national competence. The changing perception of 'best policy mix' for combatting energy poverty can thus be said to reflect both the growing EU role in this area and the economic circumstances in which it operates.

\section{Trends and Developments in EU Energy Poverty Policy}

Energy poverty policy in the EU has evolved along broadly the same path as energy policy - virtually non-existent until the mid-2000s it has become a consistent component of EU policy despite the shared competences that dictate its governance. Its primary source remains the IEM and the EU's considerable body of policy on consumer protection in the common market. Though promising indications were seen in the EED, these have not translated into a solid second source of policy, largely because of the inherent conflict with climate change and environmental objectives, particularly in the short term. More recently, the relevance of social policy has been acknowledged but the subsidiarity principle and the absence of a social policy mandate prevent the EU from developing comprehensive policy on this basis. That said, an early focus upon vulnerable consumers has shifted 
somewhat, since the onset of the economic recession, to the social dimension of energy policy and the need to combat energy poverty with a coordinated, cross-sector approach.

Evaluating the success of specific policies on energy poverty is difficult; data is lacking and many policy instruments are non-binding and flexible, meaning that Member States may choose to implement them in a number of different ways. The TEP, which required that Member States adopt a definition of vulnerable consumers and take measures to ensure that they are protected, suffered initial difficulties in implementation, resulting in the opening of a number of infringement proceedings. But its provisions relating to energy poverty are generally considered to have been well transposed-for the most part, Member States already had implicit notions of vulnerable consumers in national law and almost all have some form of measure to protect those who qualify. As such, the TEP might be deemed a 'success' in that it has raised the profile of energy poverty as an EU issue and performed a key role in laying the foundation for common discussion. Energy efficiency legislation is hard to evaluate from an energy poverty perspective because of the non-binding language in which it is couched; although this is now being gradually changed by the provisions of the Clean Energy Package. EU-level policy statements on the use of social policy instruments to combat energy poverty are vague, non-binding and, as yet, are not consolidated into a coherent policy objective.

More broadly, the 'success' of EU energy poverty initiatives might be judged by asking to what extent they have become a genuine EU policy. From this perspective, though fragmented in its approach, the EU has moved to some extent in establishing energy poverty as a European issue and laying the foundations for a coherent policy in this area. The TEP made important steps in mainstreaming energy poverty into energy policy, though some lags have been experienced in energy efficiency, for example. Since this initial introduction, almost all subsequent policy on the IEM has made reference to energy poverty as a component and policy objective, though with varying specificity and force. Furthermore, repeated emphasis of the link to other sectors, such as health, consumers and housing, has resulted in a widely recognized need for a coordinated approach in tackling energy poverty. European-level platforms have been welcomed by Member States and stakeholders and have produced valuable reviews of existing practice and recommendations for further action, as well as highlighting the necessity and benefit of a common EU approach. As such, and 
in spite of its imbalanced competence in the relevant areas, the EU has succeeded in taking the first steps to making energy poverty a European policy issue.

\section{Actors and Stakeholders in EU Energy Poverty Policy}

The driving actor in pushing an EU energy poverty policy forward has been the European Commission. Following numerous failed attempts to create a common energy policy framework prior to 2007, the Commission has ensured that energy poverty forms an important strand of the now wide-ranging EU action in energy. As in all areas of EU policy, the Commission acts as the primary agenda-setter in energy policy, initiating and drafting legislation but restrained in its financial and administrative resources, as well as its legal mandate (Birchfield, 2011). The individual DGs are also important for expanding and developing energy poverty policy and have been relatively effective in framing and defining it as a problem which should be dealt with by the DGs for environment, health, consumers and, to some extent, foreign relations, in addition to DG Energy. Implementation of the various instruments and legislation has also been supported by DG Competition, which has stepped in when Member States have not fully transposed IEM rules or implemented other energy regulations. Support with enforcement has also been received from the Court of Justice in its role as adjudicator on infringement proceedings brought against national governments.

While the Commission has carefully balanced its energy policy goals with its constitutional asymmetry and need to achieve sufficient member state support, other EU institutions have been outspoken about the necessity of a coherent EU energy poverty policy. Both the European Parliament and the EESC have made bold statements about the social dimension of energy poverty, the pan-European nature of the problem, the lack of sufficient action on the part of Member States and the need for the EU to exercise its indirect influence in spite of its competence weakness. This impetus for greater EU involvement is supported by the research and resources gathered by the various platforms and stakeholder groups at the EU level. Bodies such as the CEF and the VCWG have been instrumental in making available the kind of background research on existing practice and areas for improvement called for in early energy 
poverty policy statements, thus paving the way for further action; and energy poverty has received frequent attention at high-level fora such as EU Sustainable Energy Week (Fig. 3.1).

This driving support and impetus for action is weathered by the somewhat more passive role of Member States. Reluctant to cede any more responsibility in the energy sector than is necessary for the functioning of the Single Market, the various configurations of the Council have been careful to moderate the momentum of Commission activity, preferring in most cases to use soft law mechanisms and non-binding measures to pursue common objectives, rather than legislative solutions.

Consequently, energy poverty policy has an 'emergent and precarious nature', lacking an institutional centre and limited by its dependence upon the consumer protection agenda, which prevents it from tackling the structural conditions which cause energy and fuel poverty (Bouzarovski et al., 2012).

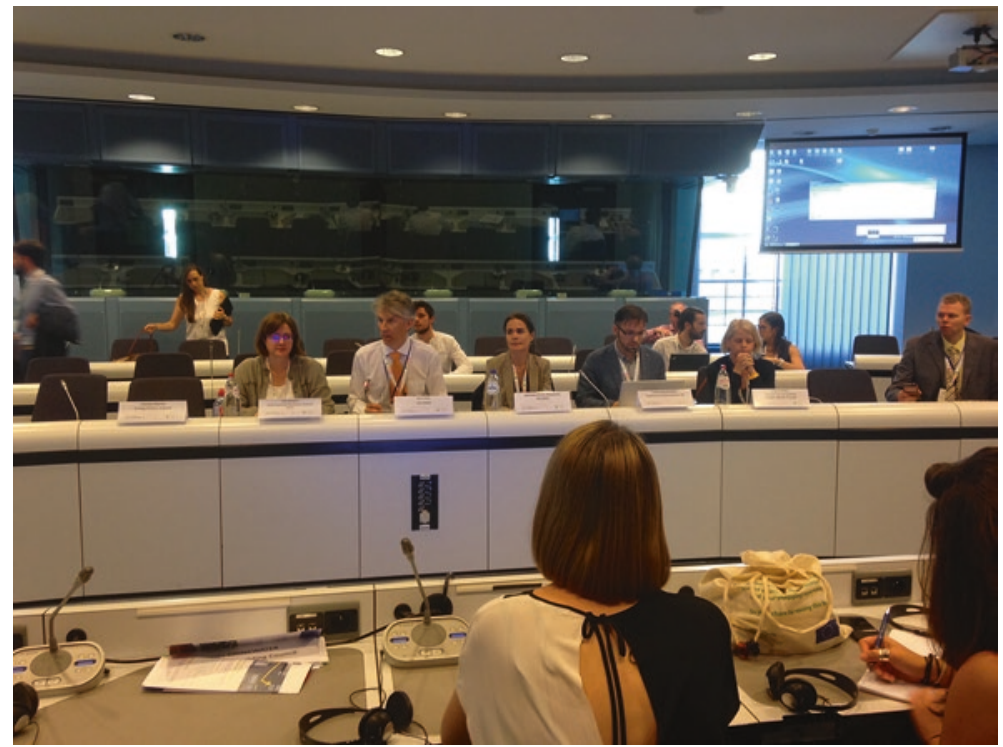

Fig. 3.1 An energy poverty session at European Energy Week, 2017 (photo by Saska Petrova) 
Historically, an EU-wide definition of energy poverty or vulnerable consumers has been deliberately avoided by the institutions because of the difficulty in designing a concept which fits with all existing national understandings. While the decision to refrain from adopting a common definition aimed to encourage Member State action by maximizing flexibility, this is identified in much of the literature as the fundamental cause of the insufficient measures taken to date and the primary barrier to more coherent EU action (Thomson et al., 2016). Different countries also require different policy mixes and measures to address energy poverty. An expert workshop held in Brussels in 2010 raised concerns that policies led by the EU showed insufficient consideration for the lack of institutional capacity to deal with energy poverty at multiple levels of governance (Bouzarovski et al., 2012); similar issues have been discussed at subsequent events (Fig. 3.2). In light of the vague and impractical nature of policy recommendations made at the EU level, the group concluded that very little direct action has therefore been taken at the different levels, and is unlikely to be taken unless a common definition and an established evidence base can be provided.

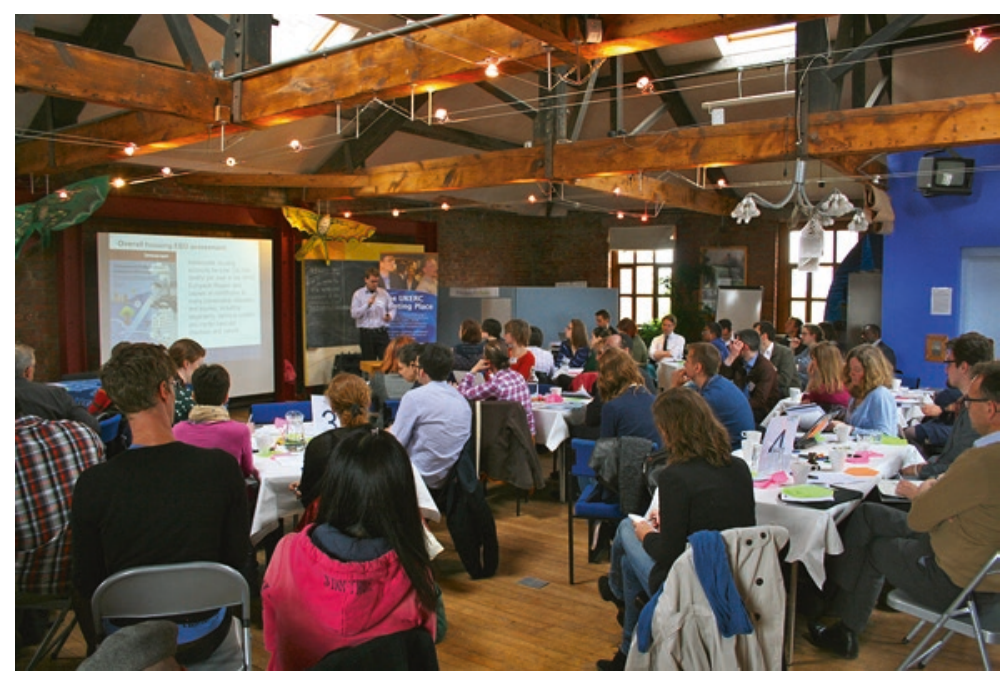

Fig. 3.2 Participants at an international conference on energy poverty and vulnerability in Manchester, in 2013 (photo by Stefan Bouzarovski) 


\section{Instead of a Conclusion: The Future of the EU Energy Poverty Policy}

The evolution of EU energy poverty to date, as tempered by the imbalance of relevant competences and disparate policy tools available, indicates that future policy development is likely to proceed along the established path of supplementing peripheral hard law with soft law instruments. But an often overlooked avenue for the development of energy poverty policy is via the EU's health agenda. Health actors have consistently taken an interest in energy poverty, and the link between lack of access to energy and poor mental and physical health in people of all ages is well established (Heffner \& Campbell, 2011). The EU's public health mandate is relatively strong; and recent research commissioned in light of the economic recession and social crisis has highlighted the relevance of energy poverty in Europe's recovery and return to growth. The health community has also been instrumental in forging the link between energy poverty and housing quality, supported by a coalition of stakeholders concerned with the quality of the housing stock and the implementation of the EED.

Technology and climate change are two other strategic directions likely to affect the direction of the EU energy poverty policy in the coming years. Smart metering - a growing priority of EU energy policy-holds the potential to combat energy poverty in some instances, but its pros and cons for energy-poor users require careful consideration (Darby, 2012). Low-carbon urban and regional development policies more generally also hold significant energy poverty reduction opportunities, especially if justice contingencies are taken into account. There are also important intersections between climate change policy and energy poverty policy-not only in terms of mitigation efforts but also in relation to the impacts of global warming on the need for additional energy services in the home, such as space cooling. These complex policy loci are at odds with the relatively unidirectional nature of EU energy poverty initiatives to date: in Bouzarovski and Petrova (2015b), we noted that agenda-shaping in the EU poverty domain has been mainly driven from above, and has been highly contingent on attempts to 'define' and 'identify' the problem. It remains to be seen whether the significant-and relatively fast-development of a distinctive EU agenda on energy poverty will be accompanied by a range of groundbreaking steps to capture the more systemic implications of the problem. 


\section{REFERENCES}

Andoura, S., Hancher, L., \& van der Woude, M. (2010). Towards a European Energy Community: A policy proposal. Brussels: Notre Europe.

Bakker, K. (2007). The 'commons' versus the 'commodity': Alter-globalization, anti-privatization and the human right to water in the global South. Antipode, $39,430-455$.

Birchfield, V. (2011). The role of EU institutions in energy policy formation. In V. Birchfield \& J. S. Duffield (Eds.), Toward a common European Union energy policy (pp. 235-262). New York: Palgrave Macmillan.

Bouzarovski, S. (2014). Social justice and climate change: Addressing energy poverty at the European scale. Brussels: Spring Alliance.

Bouzarovski, S., \& Petrova, S. (2015a). A global perspective on domestic energy deprivation: Overcoming the energy poverty-fuel poverty binary. Energy Research \& Social Science, 10, 31-40.

Bouzarovski, S., \& Petrova, S. (2015b). The EU energy poverty and vulnerability agenda: An emergent domain of transnational action. In J. Tosun, S. Biesenbender, \& K. Schulze (Eds.), Energy policy making in the EU (pp. 129-144). London: Springer.

Bouzarovski, S., Petrova, S., \& Sarlamanov, R. (2012). Energy poverty policies in the EU: A critical perspective. Energy Policy, 49, 76-82.

Commission of the European Communities. (2005). Staff working document 'Annex to the Communication from the Commission "Annual report 2005 on the European Community's development policy and the implementation of external assistance in 2004"'. Brussels: Commission of the European Communities.

Commission of the European Communities. (2007). Communication 'An energy policy for Europe'. Brussels: Commission of the European Communities. Retrieved from http://eur-lex.europa.eu/legal-content/EN/TXT/PDF/?uri $=$ CELEX:52007DC0001\&from $=\mathrm{EN}$

Council of Europe. (2008). Housing policy and vulnerable social groups. Strasbourg: Council of Europe.

Council of European Energy Regulators. (2012). Status review of customer and retail market provisions from the 3rd package as of 1 January 2012. Brussels: Council of European Energy Regulators.

Council of the European Union. (2007). Presidency conclusions. Brussels: Council of the European Union.

Council of the European Union. (2013). Progress on the completion of the Internal Energy Market. Brussels: General Secretariat of the Council.

Council of the European Union. (2014a). Completion of the Internal Energy Market. Brussels: Council of the European Union.

Council of the European Union. (2014b). Council conclusions on 'Energy prices and costs, protection of vulnerable consumers and competitiveness'. Brussels: 
Council of the European Union. Retrieved from http://www.consilium. europa.eu/uedocs/cms_data/docs/pressdata/en/trans/143198.pdf

Csiba, K. (Ed.). (2016). Energy poverty handbook. Brussels: European Parliament.

Darby, S. J. (2012). Metering: EU policy and implications for fuel poor households. Energy Policy, 49, 98-106.

Dhéret, C., \& Giuli, M. (2017). The long journey to end energy poverty in Europe. Brussels: European Policy Centre.

Directorate General for Health and Consumers. (2010). The functioning of retail electricity markets for consumers in the European Union. Brussels: ECME Consortium. Retrieved from http://ec.europa.eu/consumers/archive/consumer_research/market_studies/docs/retail_electricity_full_study_en.pdf

Dubois, U., \& Meier, H. (2016). Energy affordability and energy inequality in Europe: Implications for policymaking. Energy Research \& Social Science, 18, 21-35.

Duffield, J., \& Birchfield, V. (2011). Introduction: The recent upheaval in EU energy policy. In J. Duffield \& V. Birchfield (Eds.), Toward a common European Union energy policy (pp. 1-12). New York: Palgrave Macmillan.

Eurelectric. (2017). Energy poverty. A Eurelectric position paper. Brussels: Union of the Electricity Industry-Eurelectric.

European Anti-Poverty Network. (2017). Right to energy for all Europeans. http://www.eapn.eu/wp-content/uploads/2017/06/EAPN-2017-letter-toMEPs-Right-to-Energy-Coalition-1225.pdf. Retrieved September 1, 2017.

European Commission. (2010a). Commission staff working paper: An energy policy for consumers. Brussels: EC.

European Commission. (2010b). Communication 'Energy 2020 a strategy for competitive, sustainable and secure energy'. Brussels: European Commission.

European Commission. (2011). Communication from the European Commission to the European Parliament, the Council, the European Economic and Social Committee and the Committee of the Regions. Energy roadmap 2050. Brussels: European Commission. Retrieved from http://eur-lex.europa.eu/LexUriServ/ LexUriServ.do?uri=COM:2011:0885:FIN:EN:PDF

European Commission. (2012). Directive 2012/27/EU of the European Parliament and of the Council of 25 October 2012 on energy efficiency, amending Directives 2009/125/EC and 2010/30/EU and repealing Directives 2004/8/EC and 2006/32/EC Text with EEA relevance. http://eur-lex.europa.eu/legalcontent/EN/TXT/?uri=celex:32012L0027. Retrieved 1st September 2017.

European Commission. (2013a). Green Paper 'A 2030 framework for climate and energy policies'. Brussels: European Commission. Retrieved from http:// eur-lex.europa.eu/legal-content/EN/TXT/PDF/?uri=CELEX:52013DC01 69\&from $=\mathrm{EN}$

European Commission. (2013b). Staff working document 'Guidance for national energy efficiency action plans'. Brussels: European Commission. 
European Commission. (2013c). Vulnerable consumer working group guidance document on vulnerable consumers, November 2013. Brussels: European Commission, Vulnerable Consumer Working Group.

European Commission. (2014a). Commission staff working document energy prices and costs report. Brussels: European Commission.

European Commission. (2014b). Communication from the Commission to the European Parliament, the Council, the European Economic and Social Committee and the Committee of the Regions. Energy prices and costs in Europe. Brussels: European Commission.

European Commission. (2014c). Communication from the Commission to the European Parliament, the Council, the European Economic and Social Committee and the Committee of the Regions. Green Action Plans for SMEs. Brussels: European Commission.

European Commission. (2015). Communication from the Commission to the European Parliament, the Council, the European Economic and Social Committee and the European Investment Bank. A Framework Strategy for a Resilient Energy Union with a Forward-Looking Climate Change Policy. Brussels: European Commission. Retrieved from http://eur-lex.europa.eu/ legal-content/EN/TXT/?uri=COM:2015:80:FIN

European Commission. (2016). Commission staff working document 'Evaluation report covering the evaluation of the EU's regulatory framework for electricity market design and consumer protection in the fields of electricity and gas'. Brussels: European Commission.

European Commission. (2017a). Proposal for a directive of the European Parliament and of the Council amending Directive 2010/31/EU on the energy performance ofbuildings. http://eur-lex.europa.eu/legal-content/EN/TXT/?uri=CELEX: 52016PC0765. Retrieved September 1, 2017.

European Commission. (2017b). Proposal for a directive of the European Parliament and of the Council on common rules for the internal market in electricity (recast). http://eur-lex.europa.eu/legal-content/EN/TXT/?uri=CELEX\%3A52016P C0864R\%2801\%29. Retrieved September 1, 2017.

European Commission. (2017c). Proposal for a directive of the European Parliament and of the Council on energy efficiency and repealing Directives 2004/8/EC and 2006/32/EC. http://eur-lex.europa.eu/legal-content/en/ALL/?uri=CELEX: 52011 PC0370. Retrieved September 1, 2017.

European Commission. (2017d). Proposal for a Regulation of the European Parliament on the Governance of the Energy Union, amending Directive 94/22/EC, Directive 98/70/EC, Directive 2009/31/EC, Regulation (EC) No 663/2009, Regulation (EC) No 715/2009, Directive 2009/73/EC, Council Directive 2009/119/EC, Directive 2010/31/EU, Directive 2012/27/EU, Directive 2013/30/EU and Council Directive (EU) 2015/652 and repealing Regulation (EU) No 525/2013. http:// eur-lex.europa.eu/legal-content/EN/TXT/?uri=COM:2016:759:REV1. Retrieved September 1, 2017. 
European Council. (2015). Council conclusions on the governance system of the Energy Union. http://www.consilium.europa.eu/en/press/press-releases/2015/ 11/26-conclusions-energy-union-governance/. Retrieved September 1, 2017. European Economic and Social Committee. (2011). Opinion of the European economic and social committee on 'Energy poverty in the context of liberalisation and the economic crisis' (exploratory opinion). Brussels: European Economic and Social Committee.

European Group on Ethics in Science and New Technologies to the European Commission. (2013). Opinion no 27 'An ethical framework for assessing research, production and use of energy'. Brussels: European Commission.

European Parliament. (2012, May 22). Resolution 'strengthening the rights of vulnerable consumers'. Retrieved from http://www.europarl.europa.eu/sides/ getDoc.do? pubRef=- //EP / /NONSGML+TA+P7-TA-2012-0209+0+ $\mathrm{DOC}+\mathrm{PDF}+\mathrm{V} 0 / / \mathrm{EN}$

European Parliament. (2013a). European Parliament resolution of 14 March 2013 on the Energy roadmap 2050, a future with energy. http://www.europarl. europa.eu/sides/getDoc.do?pubRef=- //EP / /TEXT+TA+P7-TA-20130088+0+DOC+XML+V0//EN. Retrieved September 1, 2017.

European Parliament. (2013b). Report on social housing in the European Union. http://www.europarl.europa.eu/sides/getDoc.do?pubRef=- / / EP// NONSGML+REPORT+A7-2013-0155+0+DOC+PDF+V0//EN. Retrieved September 1, 2017.

Grave, K., Breitschopf, B., Ordonez, J., Wachsmuth, J., Boeve, S., Smith, M., ... Schleich, J. (2016). Prices and costs of EU energy. Utrecht: Ecofys Netherlands.

Heffner, G., \& Campbell, N. (2011). Evaluating the co-benefits of low-income energy-efficiency programmes. Paris: International Energy Agency.

Hiteva, R. P. (2013). Fuel poverty and vulnerability in the EU low-carbon transition: The case of renewable electricity. Local Environment, 18, 487-505.

Intelligent Energy Europe. (2017). European fuel Poverty and Energy Efficiency (EPEE). https://ec.europa.eu/energy/intelligent/projects/en/projects/ epee. Retrieved September 1, 2017.

McCormick, J. (2014). Understanding the European Union: A concise introduction. London: Palgrave Macmillan.

Official Journal of the European Union. (2009). Directive 2009/73/EC of the European Parliament and of the Council of 13 July 2009 concerning common rules for the internal market in natural gas and repealing Directive 2003/55/EC (Text with EEA relevance). http://eur-lex.europa.eu/legal-content/EN/ ALL/?uri=CELEX:32009L0073. Retrieved September 1, 2017.

Official Journal of the European Union. (2012). Consolidated version of the Treaty on the Functioning of the European Union. http://eur-lex.europa.eu/legalcontent/EN/TXT/?uri=CELEX:12012E/TXT. Retrieved September 1, 2017. 
Pellerin-Carlin, J., Vinois, J.-A., Rubio, E., \& Fernandes, S. (2017). Making the energy transition a European success: Tackling the democratic, innovation, financing and social challenges of the energy union. Paris: Jacques Delors Institute.

Pye, S., Baffert, C., Brajković, J., Grgurev, I., Miglio, D. R., \& Deane, P. (2015). Energy poverty and vulnerable consumers in the energy sector across the EU: Analysis of policies and measures. London: Insight_E.

Rademaekers, K., Yearwood, J., Ferreira, A., Pye, S., Hamilton, I., Agnolucci, P., ... Anisimova, N. (2016). Selecting indicators to measure energy poverty. Brussels: European Commission, DG Energy.

S\&D Manifesto. (2017). Fighting energy poverty—SerD Manifesto. http://www. socialistsanddemocrats.eu/publications/fighting-energy-poverty-sdmanifesto. Retrieved September 1, 2017.

Thomson, H., Snell, C., \& Liddell, C. (2016). Fuel poverty in the European Union: A concept in need of definition? People Place and Policy, 10, 5-24.

Walker, G. (2015). The right to energy: Meaning, specification and the politics of definition. L'Europe en Formation, 378(4), 26-38.

Open Access This chapter is distributed under the terms of the Creative Commons Attribution 4.0 International License (http://creativecommons.org/licenses/ by $/ 4.0 /)$, which permits use, duplication, adaptation, distribution and reproduction in any medium or format, as long as you give appropriate credit to the original author(s) and the source, a link is provided to the Creative Commons license and any changes made are indicated.

The images or other third party material in this chapter are included in the work's Creative Commons license, unless indicated otherwise in the credit line; if such material is not included in the work's Creative Commons license and the respective action is not permitted by statutory regulation, users will need to obtain permission from the license holder to duplicate, adapt or reproduce the material.

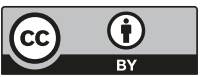

